\title{
THE DEVELOPMENT OF BUS STATION KAMPUNG RAMBUTAN IN EAST JAKARTA WITH ART DECO STYLE
}

\author{
Randy Afriandi \\ Architectural Engineering, Faculty of Engineering, \\ Mathematics \& Natural Sciences, Universitas Indraprasta PGRI \\ randyafriandi@yahoo.com
}

\begin{abstract}
The purpose of this paper is the realization of the concept of space into a form of human activity through technology approach that is more directed to the physical building, so the transportation building is expected to fully functional as a public space. The Design method are by conducts field surveys, sketches ideas / concepts, drafts the floor plans, elevates, section and the development of three-dimensional design. Public transport infrastructure facilities is a fundamental requirement of economic activities of DKI Jakarta. Transportation which is fast, inexpensive, and convenient has been an absolute necessity for the city of Jakarta. Bus station which also serves as a transfer is part of the concept of the provision of public transport. Bus station as a 'public reception room' in a city would be expected to have adequate infrastructure and equipped spatial comfortable, and clean.
\end{abstract}

Keywords :Bus Station, Kampung Rambutan, Jakarta, Art Deco.

\section{PENGEMBANGAN TERMINAL BUS KAMPUNG RAMBUTAN JAKARTA TIMUR BERGAYA ART DECO}

\begin{abstract}
Abstrak
Tujuan penelitian ini adalah merealisasikan konsep ruang kedalam bentuk aktivitas manusia lewat pendekatan teknologi yang mengarah ke bangunan fisik, jadi gedung transportasi dapat secara penuh berfungsi sebagai ruang publik. Metode desain adalah dengan melakukan survey lapangan, sketsa ide, membuat draf floor plan, mengevaluasi, mengelompokkan dan membangun desain 3 dimensi. Fasilitas infrastruktur kendaraan umum merupakan kebutuhan dasar aktivitas ekonomi DKI jakarta. Transportasi yang cepat, tidak mahal, dan nyaman adalah sebuah kebutuhan mutlak bagi kota Jakarta. Terminal bis yang juga berfungsi sebagai tempat perpindahan adalah termasuk bagian dari konsep ketetapan (pasal) mengenai transportasi publik. stasiun bis sebagai 'ruang penerimaan publik' di sebuah kota diharapkan memiliki cukup infrastruktur dan dilengkapi dengan ruang yang nyaman, dan bersih.
\end{abstract}

Keywords : Terminal Bus, Kampung Rambutan, Jakarta, Art Deco. 


\section{INTRODUCTION}

The mobility of peoples in Jakarta rise the demand of transportation. Jakarta urban mobilities that is high enough to encourage the creation of high transport as well, in terms of both quality and quantity. The problem of transportation system will be closely linked to the provision of transport modes and infrastructure of highways and bus terminals as a whole aspect that influence each other.

Jakarta is the center of business and government. There have been many theories applied to overcome the transportation problems, but still does not provide an effective solution. Unavailability of alternative modes of circulation resulting in the entire burden is on the road infrastructure, while the low availability of public transport led to very high dependence on private vehicle. The underlying issue is less the maximum of information provided to the user terminal may not know for sure about the destination and route that passed, according to the transport route that will be used, and also the issue of customs public transport drivers who often "mengetem" (linger waiting for passengers), so that passengers often late to get to the destination.

The purpose of this design is to create the shape of the building representative Terminal visually to show the identity of the city in appearance and in accordance with the draft standard in quality and can accommodate the user capacity of the Bus Terminal in scale national service. It is also to create quality spaces and circulation patterns, so as to provide a clear orientation in the circulation as well as the orientation of functional space.

\section{Literature Review}

City transportation

Transport has a sense as the movement of people or goods or a place to get to another place or vice versa with a certain distance.

So, the city transportation is the movement of people and goods within the city, including the movement of people from the city (urban) to the suburbs (suburban) or vice versa.

Transport has five elements, namely humans, vehicles, goods, road and organizations.

\section{Station}

Station is the point where passengers and goods in and out of the system, as well as an important component of the transportation system. Its function as a node in the road transport network, serves as a public services and as well as transport infrastructure that is part of the transport system to ease the flow of traffic passengers and goods. There are two types of station, passenger terminal and cargo terminal.

\section{Art Deco}

Art Deco is a style of architecture that was born before World War II and after World War I ended, circa 1920 to 1930. Art Deco phrase which stand for Decorative Art was first introduced in 1966 in the catalog published by the Musee des Arts Decoratis in Paris, who was holding an exhibition entitled "Les Annes 25" which aims to revisit the international exhibition "Exposition Internationale des Art Decoratifs et Industriels Modernes" (Exposition International's Art Industrial and Decorative Modern) held in 1925 in Paris. The development of Art Deco architecture in Jakarta begins with the arrival of European traders to trade, where the Kota Tua area of the center of 
government at that time and became one of the starting point of the growth of Art Deco architecture in the city.

Cultural system, social system, and the system can be affected by other technology architecture. The changes in the form of architecture are influenced by many aspects, but the change just one aspect in the life of society can influence the architectural form.

Art Deco adopted the style that accentuates the basic form of the building with columns Doric, Ionic and Corinthian with various forms of ornamentation on his capital. Traps stairs up (cripedoma) Forms tympanum (the wall construction is triangular or semicircle) is placed on doors and windows serve as decoration.

\section{METHOD}

The design method used is to conduct field surveys, sketches ideas / concepts, drafts the floor plans, elevates, section and design development with three-dimensional illustration.

\section{Field survey}

The data that collected divided into two, they are primary data and secondary data, where primary data is taken directly through field surveys, while secondary data is data obtained from the relevant local government agencies.

\section{Sketches the ideas / concepts}

After data on needs such as existing data, topography, location and photos obtained, it then followed by drafts a design or sketch design of each job.

\section{Prelimenary design}

The steps needed to achieve a good design, such as the floor plans, elevations of the building, detail and design development with threedimensional illustration.

\section{RESULTS}

\section{Function}

Principals' activities

Principals' activities can be divided into two categories, they are terminal service users and terminal service providers. That both activities at the terminal antar kota and terminal dalam kota, busway and supermarkets.

Space needs

According to the Ministry of Transportation Decree No. 31, 1995 Articles 3 and 4, the main facilities that should be there in every terminal is a lane departure and arrival of public transport, park and rest area public transportation, office buildings terminal, waiting room, watchtowers, the ticket counters and signs and information boards containing instructions majors, rates and itineraries. Besides supporting facilities are the toilets, mosque, kiosk/cafeteria, clinic, information center, deposit counter, and a garden.

The existence of various support facilities at the terminal that provides comfort is one of the main factors that affect the public interest to use the vehicle. The need for support facilities which is attached to Kampung Rambutan Bus Terminal, the ATM center, escalators and moving walks, shops, kiosks / tenant and supermarkets.

\section{Site analysis}

Project location

Location Kampung Rambutan Bus Terminal is located in Jalan lingkar Luar Selatan, Kelurahan Rambutan, Kecamatan Ciracas, Jakarta Timur 13830. Jagorawi toll road in the east, Jalan Lingkar Luar Selatan in the north, 
Kali Cipinang Timur in the West and Residential area in the South bordering.

Land use

In accordance with the Zoning Regulations and Detailed Spatial Plan of Jakarta in 2014, the land use is Zone Public and Social Services as Infrastructure Terminal. The terminal is managed by the Jakarta Department of Transportation.

Directions to the location

From the direction of Cilandak, Pasar Minggu and Jalan Pasar Rebo through. Jalan TB. Simatupang, passes through the intersection and Pasar Rebo interchange turn at Kampung Rambutan, under the Toll Pondok Pinang-TMII. Bus terminal will be on the left. From the directions of Pondok Gede and Tamini Square through J1. Raya TMII Door 1, turn right at the interchange Kampung Rambutan. From the straight-through Jalan Taman Mini. Headquarters of Defence, after going through J1. Toll TB. Simatupang, the position of the site is on the left. From directions Ceger or Bungur through Jl. Bungur and turn left at the interchange Kampung Rambutan.

Traffic conditions

Jalan lingkar Luar Selatan is a one-way. Traffic congestion often occurs in Jalan TB. Simatupang and Jalan lingkar Luar Selatan, due to higher volume of vehicles. It is also caused by the presence of "Terminal Bayangan" area near the toll booths. More precisely, at the intersection of Jalan Pasar Rebo and the u-turn of Jalan Tanah Merdeka. The density of the public transportation is mostly because of the buses that will use toll roads in the areas.

\section{BCR and FAR}

According to the building regulations, Kampung Rambutan Bus
Terminal has the BCR (Building Coverage Ratio) 20\%, FAR (Floor Area Ratio) 0.8, and a maximum building height of four floors. Thus, the permitted floor area of $28.200 \mathrm{~m}^{2}$ and a total floor area permitted for $112.800 \mathrm{~m}^{2}$.

Land potential

The area has some potential, which lies in the area of the lively, close to the business center, on the major street (Jl. Lingkar Luar Selatan), close to the Taman Mini Indonesia Indah (TMII), has many transportation network (busway, AKDP, AKAP), close to the highway in the city and an area that 'life', as it is located in a bustling area pass through.

Climate analysis

Climatic conditions blanketed the East Jakarta City that are in the air pressure around $1009.2 \mathrm{mb}$ and the humidity is an average of 79.0 percent. Also, 4.1 knots of wind velocity and wind direction in January to March to the north, April to September toward the east, and from October to December to the West. October to December wind direction often cause heavy rains as well as other regions in Indonesia.

\section{Zoning}

Zone divided over the facility to the passengers/ visitors and terminal areas for service providers separate but interconnected with both among activities.

Building Regulations

The Director General of Land No. 272 / HK. 105 / DrJD / 96 of 1996, Decree No. 31 In 1995, the Government Regulation No. 43 of 1993 and Law No. 22 of 2009.

Parking needs

Calculation of car parking spaces $=$ effective area of the building $/ 100 \mathrm{~m}^{2} \mathrm{x}$ 
3.5. $\left(17208 \mathrm{~m}^{2} / 100 \mathrm{~m}^{2}\right) \times 3.5=602.28$

$\sim 600$ Parking Space

\section{Shape transformation}

Transformation shape is Linear, Symmetric and Repeatation in accordance with the style of Art Deco architecture.

\section{Concept}

Zone Plan

Public zones placed after the entrance and exit as the reception area. This zone is located in the front and middle of the footprint that serves as an active space that embodies the user interaction and the building became the center of activity that is easily reached from all directions. Semi-public zones placed after public zones, functioning welcomes and accepts the direction of the pedestrian who came from the busway station and the front area. Zone service is placed behind to avoid the "dead space". In this zone there are various utility systems of buildings such as the generator room, pump house, and Dumpster. Besides Restroom for the driver, bus testing area and AKAP bus parking is also placed in this zone. Private zone located beside the semi-public zone devoted to busway parking garages and parking busway and also SPBGs.

\section{Organizations space}

Basement floor is devoted to the private car park. On the ground floor is an area for supermarkets \& tenant / café and reception area for visitors / passengers whom use private vehicles. $1^{\text {st }}$ floor into an area liaison between spaces and for convenience, the bus terminal is placed on the $2^{\text {nd }}$ floor with escalators and lifts as connecting transportation inside the building.
Structure

The bottom / foot building (foundation) which acts as a conduit loads are distributed into the ground. There are several things that need to be considered in determining a suitable foundation system. The system is the appropriate structure pile foundation. As for the upper-structure, the structure chosen is the structure consisting of various alternatives, namely: folding field structure, the structure of the curved area with many combinations.

\section{Utilities}

The transport systems (freight) in a building used include elevators (lifts), Escalator and Moving Sidewalk. Providing clean water in the building is supplied from the Perusahaan Air Minum (PAM) Jakarta. Distribution system in building is done by Ground Water Tank and pumped transfer. As for the water treatment process chosen by the anaerobic-aerobic biofilter system that consists of several parts: the initial sedimentation basin, biofilter anaerobic (anoxic), aerobic biofilter, final sedimentation basin.

\section{Lighting systems}

The power source comes from PLN and is also equipped with a generator that operates when the flow of electricity is disconnected. As for some of the lighting system used is a system of direct lighting, diffus lighting and indirect lighting.

\section{Air system}

In the main building, given a forced-air systems artificial air conditioning systems air conditioning VRV (Variable Refrigerant Volume), System VRV is a kind of multi-split air conditioners for buildings that use control refrigerant flow variable which is a technology that has been equipped with a 
CPU and a compressor inverter due to VRV system, the outdoor can be used for indoor AC 2 or more with a combination of split air conditioner, wall mounted, duct, central, and others in the building.

\section{Telecommunication}

Some telecommunication system used is a phone which uses a system of PABX (Private Automatic Branch Exchange) as a telephone exchange building for incoming and outgoing calls within the scope of building internal relationships and external relations, Internet facilities and also a free Wifi (Wireless Fidelity) for passenger terminal throughout the public areas of the building. Besides, the sound system is essential in building a terminal that serves to provide a lot of information to the visitor/passenger terminal.

Fire Fighting System

Fire fighting systems used include smoke detector, automatic spinkler, fire Image Design

Site Plan

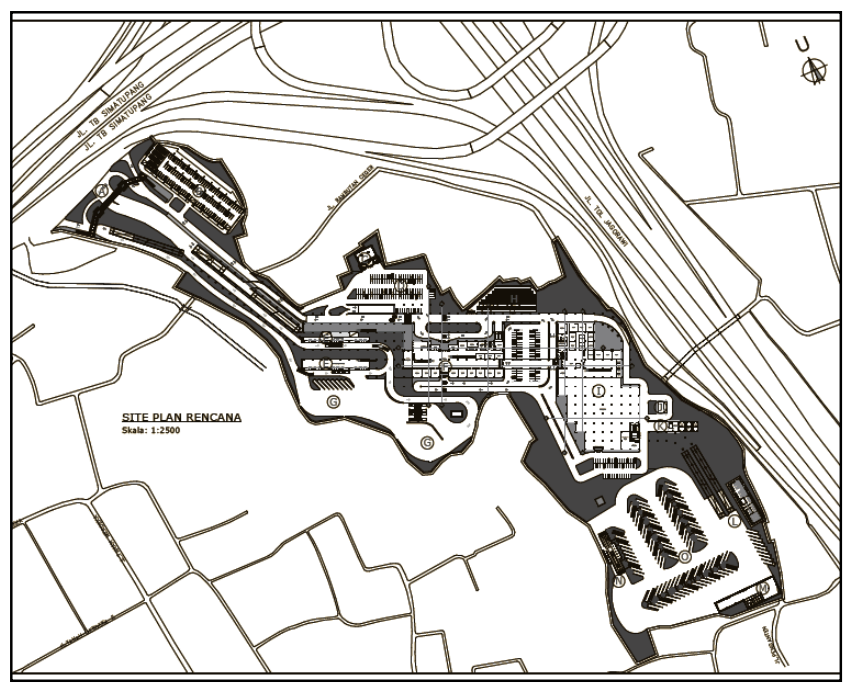

Site Plan Terminal Bus Kampung Rambutan alarm system, fire hydrant indoor / outdoor and portable chemical.

Security system

Some alternatives include security systems, CCTV cameras in every corner of the building, an x-ray scanner and metal detectors were placed at the entrance of the building.

\section{Waste Disposal System \\ Bins are placed some service} areas on each floor and some public areas such as toilets, food court, corridors and others. Garbage is collected by type, namely organic and inorganic waste. Waste is then stored in the Dumpster and then trucked to landfills.

\section{Landscape}

Some systems for greening and landscaping, among others, by planting some shade plants, shrubs and ornamental plants. 
Block Plan

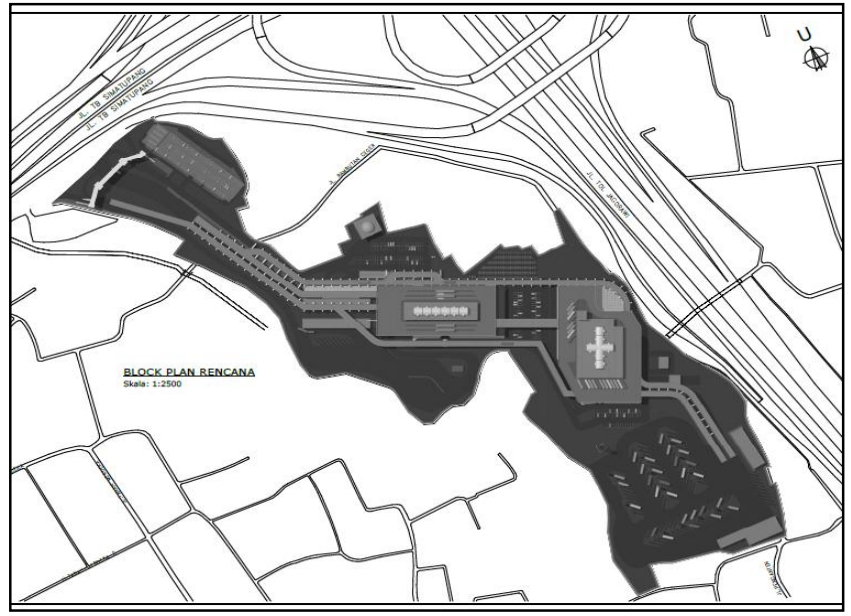

Block Plan Terminal Bus Kampung Rambutan

Plans

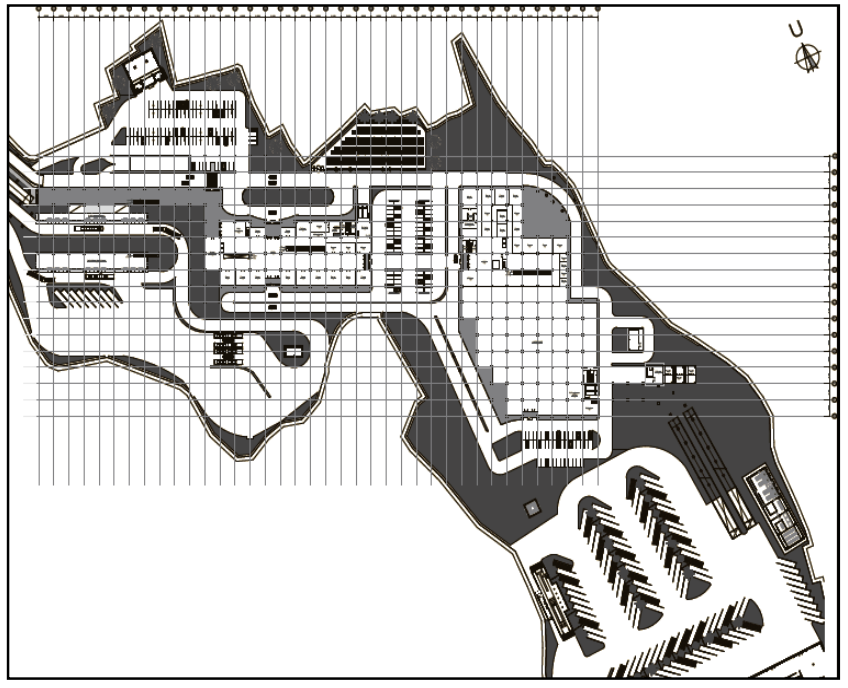

Ground Floor Plan

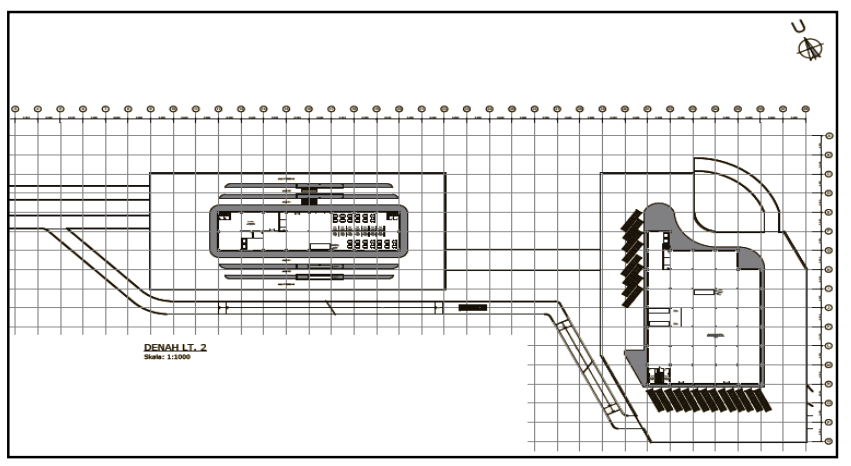

$2^{\text {nd }}$ Floor Plan 


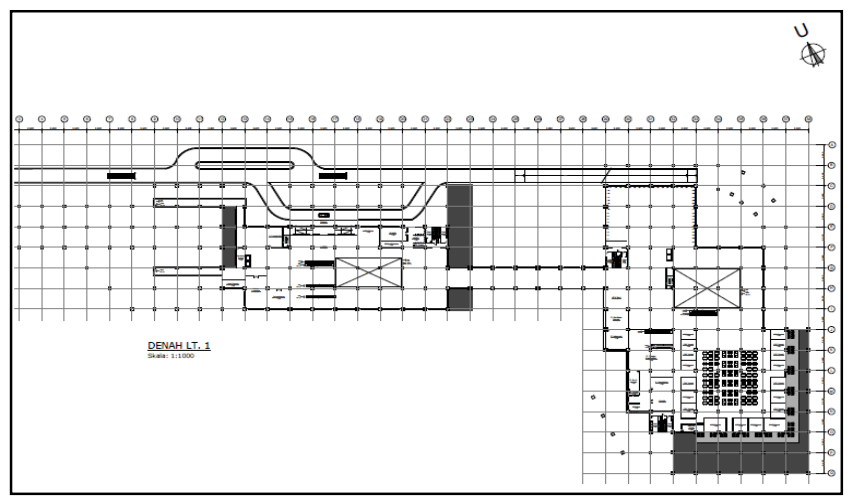

$1^{\text {st }}$ Floor Plan

Elevations
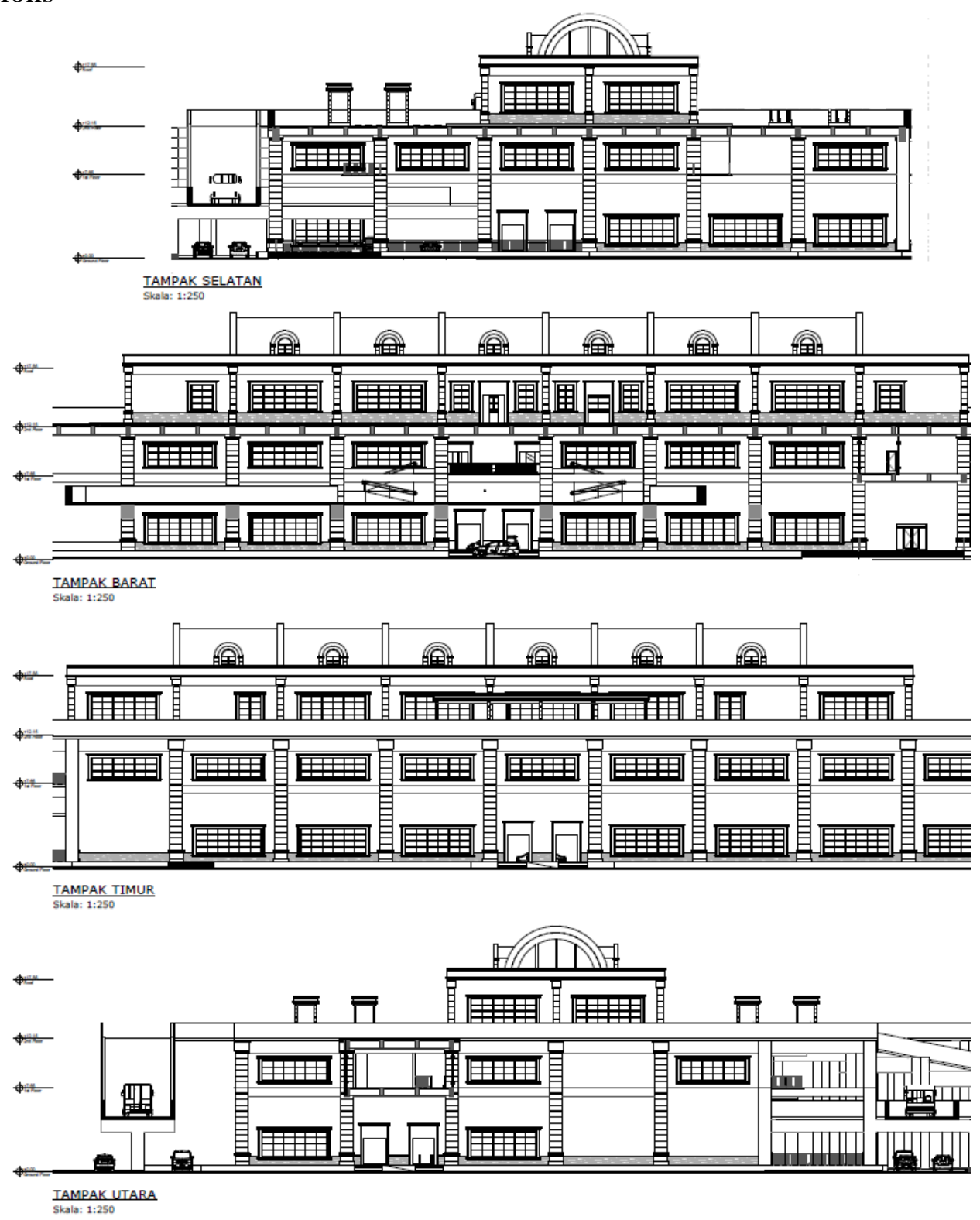

Building Elevations of Terminal Dalam Kota Kampung Rambutan 

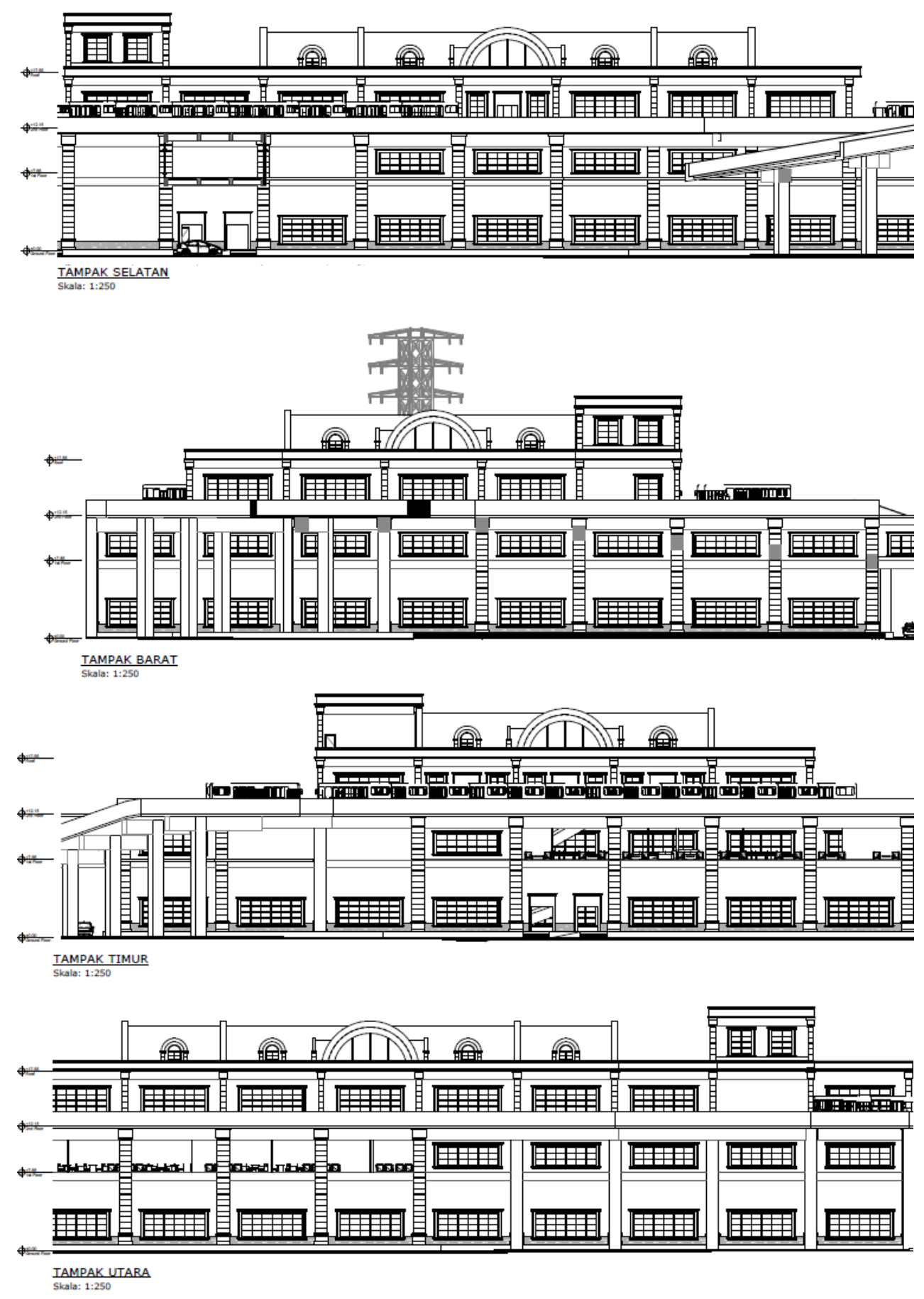

Building Elevations of Terminal Antar Kota Kampung Rambutan 
Sections
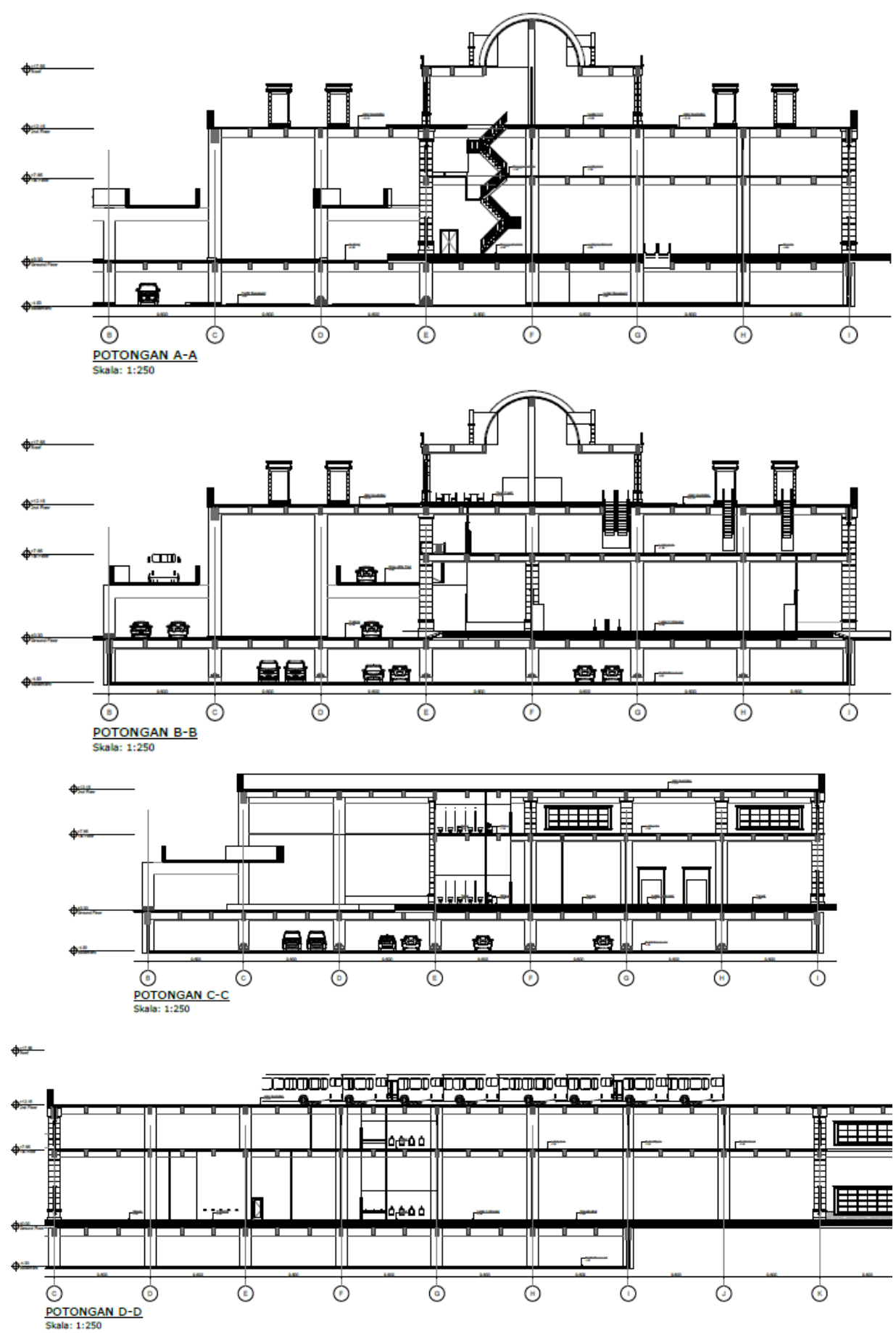

Section A-A, B-B, C-C dan D-D

Terminal Bus Kampung Rambutan 

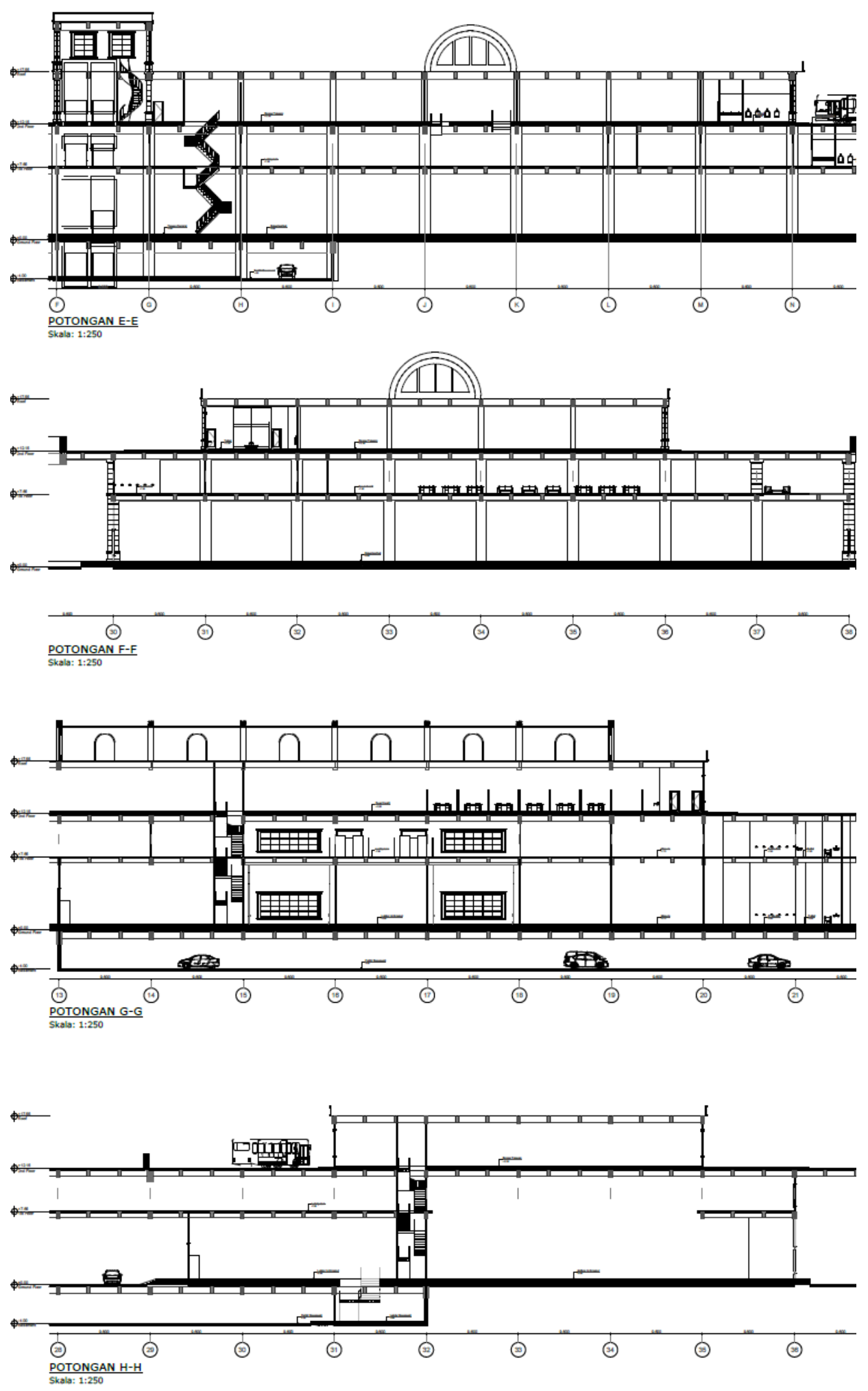

Section E-E, F-F, G-G dan H-H

Terminal Bus Kampung Rambutan 


\section{Perspective/ 3D View}
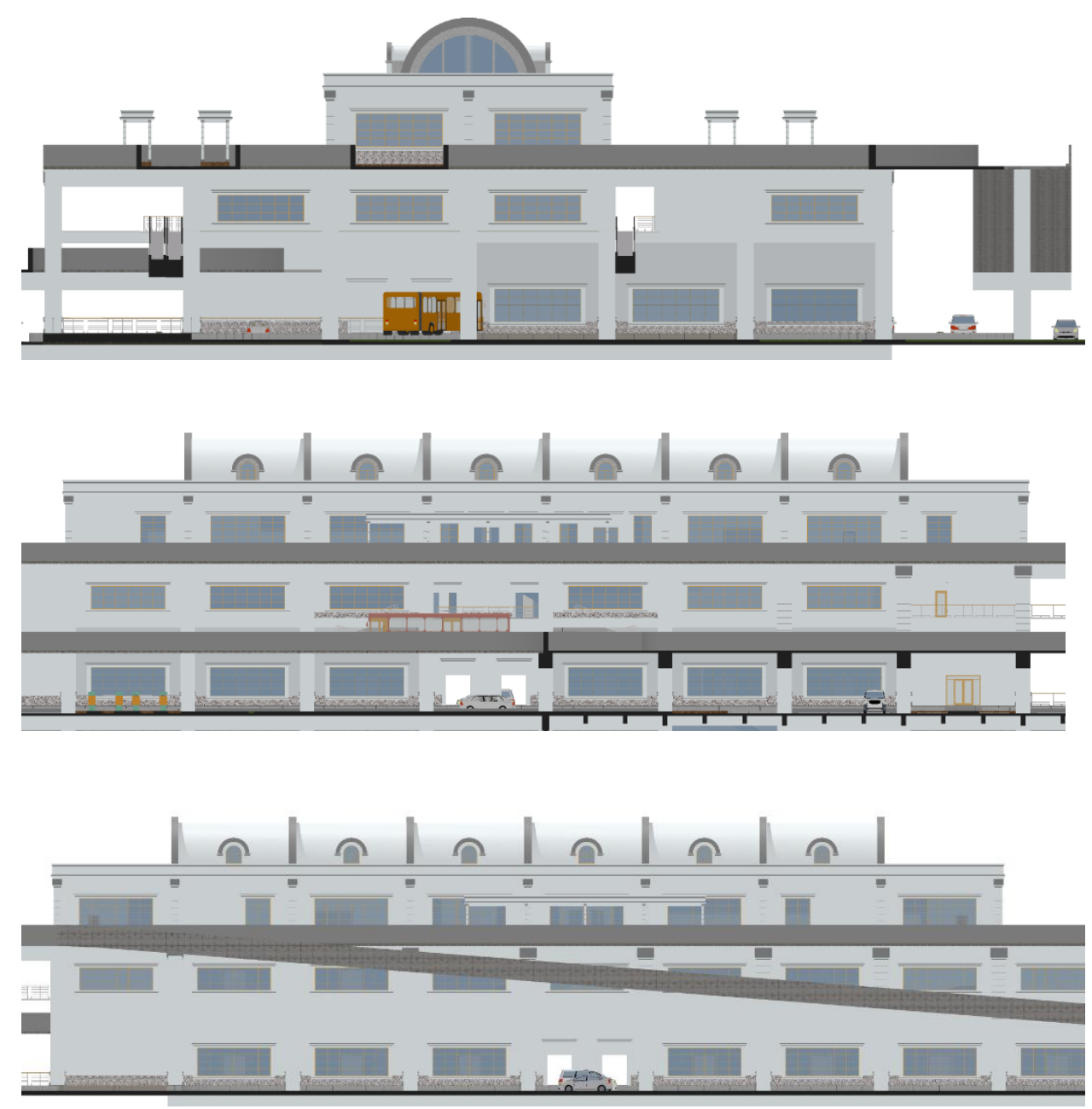

Front \& Side 3D View of Terminal Dalam Kota

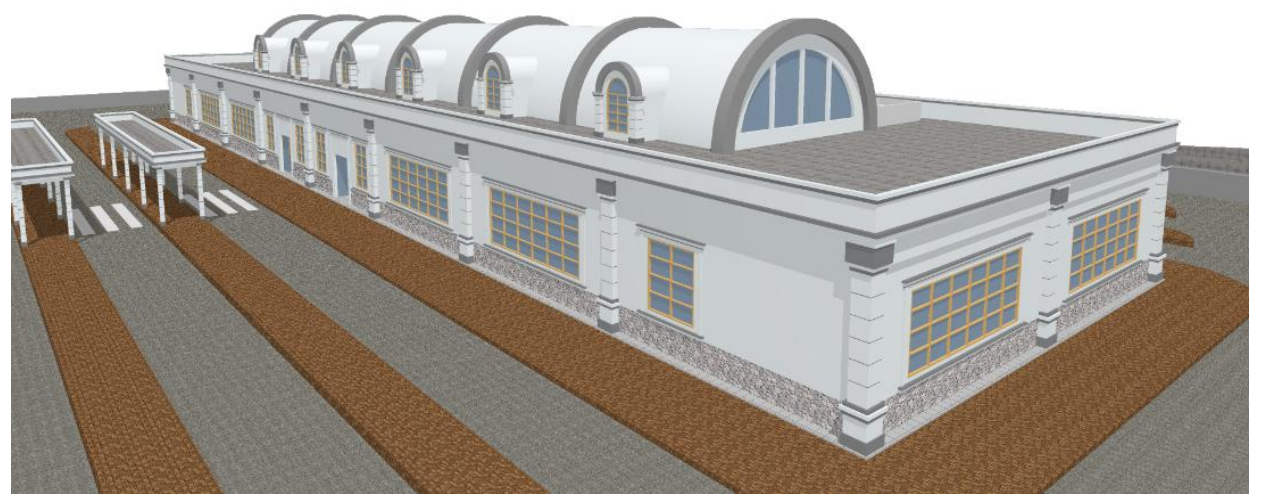

3D View of Terminal Dalam Kota 

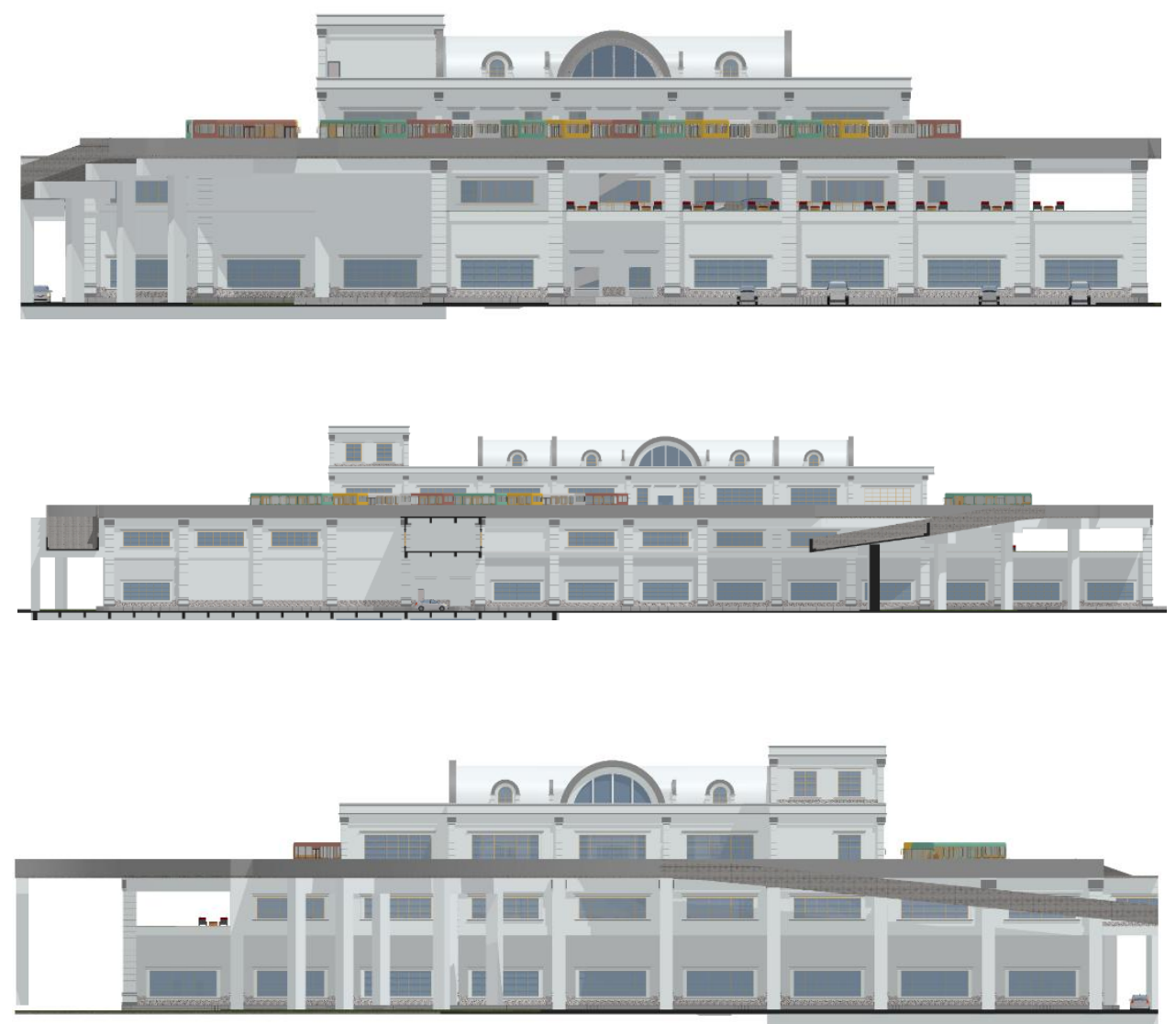

Front \& Side 3D View of Terminal Antar Kota

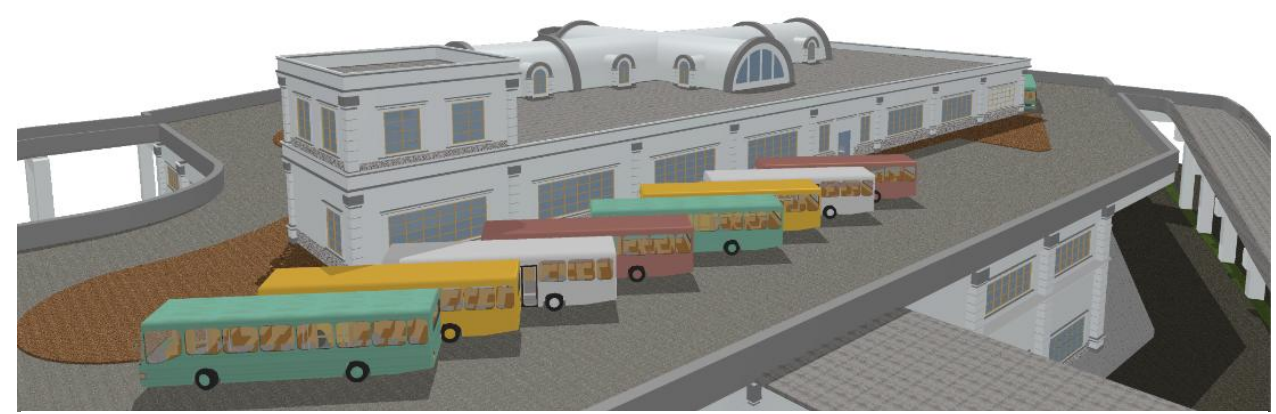

3D View of Terminal Antar Kota

\section{CONCLUSIONS}

Kampung Rambutan Bus Terminal is one of the major terminals are 'busy' in Jakarta, but is known not too friendly, because the density of passengers, disorder, and also posed a seedy impression.

Terminal as a 'public reception room' in a city would be expected to have an adequate infrastructure and include spatial comfortable, safe and clean.
Therefore, with the development of the Bus Terminal Kampung Rambutan expected Jakarta public in general and the public primary center in East Jakarta in particular will prefer public transport to travel within and outside the city because of the complete facilities and good infrastructure so that users of public transport was safer and more convenient public transportation up and down inside the terminal. In addition, in one effort to 
reduce the congestion of the city can be reached.

Accordingly, the authors give advice based on the conclusions derived, is about Standard Operating predefined on every aspect of the terminal to be implemented more efficiently and effectively to promote the goals of the terminal safe, comfortable and clean. Therefore, with the expansion of the terminal, should management and maintenance of the terminal by private parties with a form of cooperation between the Government of Jakarta with the private sector in the form of BOT (Build Operate and Transfer) that the management and maintenance of buildings still have assets that have potential economic value. Besides making terminal as a means of public transport with good infrastructure, is the responsibility of all parties, not only the Government and the Department of Transportation. However, the cooperation of all communities and service user terminal are needed.

\section{BIBLIOGRAPHY}

Books:

Anton M. (1988). Kamus Besar Bahasa Indonesia. Jakarta: Balai Pustaka.

Bachman, L. R. (2002). Integrated Building: The Systems Basis of Architecture. New York: John Wiley \& Sons.

Bayer, P. (1992). Art Deco Architecture: design, decoration and detail from the twenties and thirties. London: Thames \& Hudson.

Budiharjo, E. (1997). Jati Diri Arsitektur Indonesia. Padang: Universitas Negeri Padang.

Ching, F. (1996). Architecture, Form, Space \& Order. New York: John Wiley \& Sons.
Direktorat Penyelidikan Masalah Bangunan. (1983). Peraturan Pembebanan Indonesia Untuk Gedung. Bandung: Yayasan Lembaga Penyelidikan Masalah Bangunan.

Duncan, A. (1988). Encyclopedia of Art Deco. London: Headline Book Publishing.

Juwana, J.S. (2005). Sistem Bangunan Tinggi. Jakarta: Erlangga.

Kartono, J. L. (1995). Kebudayaan, Gaya Hidup Dipengaruhi Oleh Aspek Sosial Budaya dengan dan Arsitektur. Surabaya: Universitas Kristen Petra.

Kementerian Budaya dan Pariwisata. (2004). Standard Toilet Umum Indonesia. Jakarta: Perpustakaan Departemen Pekerjaan Umum.

Morlok, E.K. (1985). Pengantar Teknik dan Perencanaan Transportasi. Jakarta: Erlangga.

Neufert, E. (1997). Data Arsitek, Edisi 33. Jakarta: Erlangga.

Pickard, Q. (2005). The Architect's Handbook. New York: Blackwell Science.

Online Documents:

Badan Meteorologi, Klimatologi, Dan Geofisika. (2014). http://www.bmkg.go.id/BMKG Pusat, accessed on 5 October 2014.

Badan Pengembangan dan Pembinaan Bahasa, Kementerian Pendidikan dan Kebudayaan. (2014). Kamus Besar Bahasa Indonesia. http://kbbi.web.id, diakses pada 5 Oktober 2014.

Badan Pusat Statistik Kota Administrasi Jakarta Timur. (2014). Berita 
Resmi

Statistik.

http://jaktimkota.bps.go.id,

accessed on 7 October 2014.

Daikin. (2014). VRV - Multi-Split Type Air Conditioners. http://www.daikin.com/products/ ac/lineup/vrv/, accessed on 8 October 2014.

Delahunt, M. ArtLex Art Dictionary. http://www.artlex.com, diakses pada 13 Oktober 2014.

Dinas Perhubungan Kota Surabaya. (2014). Profil Terminal. http://purabayabusterminal.word press.com, accessed on 8 October 2014.

Dinas Tata Ruang Provinsi DKI Jakarta. (2014). Rencana Detail Tata Ruang. $\quad$ www.dtr.jakarta.go.id, accessed on 6 October 2014.

Juster, R. (2000). Decopix - The Art Deco Architecture Site. http://http://www.decopix.com, accessed on 13 October 2014.

Kementerian Kehutanan Republik Indonesia. (2014). Profil Kehutanan Provinsi. http://www.dephut.go.id/index.p $\mathrm{hp} /$ news/kehutanan_propinsi, accessed on 7 October 2014.

Kementerian Pekerjaan Umum. (2011). Kebijakan Mengatasi Kemacetan Di Jakarta: Menuju Penguatan
Peran Departemen PU. http://www.pu.go.id/isustrategis/ view/24, accessed on 5 October 2014.

Pemerintah Kota Administrasi Jakarta Timur. (2014). Portal Resmi Provinsi DKI Jakarta. http://timur.jakarta.go.id, accessed on 7 October 2014.

Pribadi, A. (2014). BUMD Akan Kelola Terminal DKI. http://wartakota.tribunnews.com/ 2014/02/03/bumd-akan-kelolaterminal-dki, accessed on 5 October 2014.

Regulations and Laws:

$\begin{array}{cr}\text { Keputusan Direktur } & \text { Jenderal } \\ \text { Perhubungan Darat } & \text { No. } \\ \text { 272/HK.105/DRJD/96 } & \text { Tahun } \\ \text { 1996 tentang Pedoman } & \text { Teknis } \\ \text { Penyelengaraan Fasilitas Parkir. } 8 \\ \text { April 1996. }\end{array}$

Keputusan Menteri Perhubungan No. 31 Tahun 1995 tentang Terminal Transportasi Jalan. 28 July 1995.

Peraturan Pemerintah No. 43 tahun 1993 tentang Prasarana dan Lalu Lintas Jalan. 14 July 1993.

Undang-undang No. 22 tahun 2009 tentang Lalu Lintas dan Angkutan Jalan. 22 June 2009 